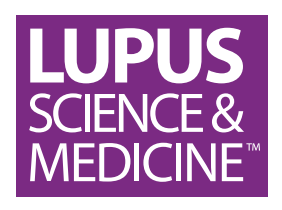

To cite: Scolnik M, Marin J, Valeiras SM, et al. Incidence and prevalence of lupus in Buenos Aires, Argentina: a 11-year health management organisation-based study. Lupus Science \& Medicine 2014;1:e000021. doi:10.1136/lupus-2014000021

- Additional material is available. To view please visit the journal online (http://dx. doi.org/10.1136/lupus-2014000021).

Received 29 January 2014 Revised 28 April 2014 Accepted 2 May 2014

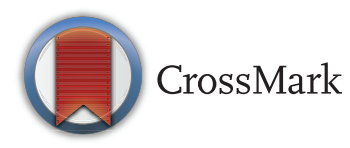

\footnotetext{
${ }^{1}$ Rheumatology Section, Medical Services, Hospital Italiano de Buenos Aires, and Fundacion Pedro M. Catoggio para el Progreso de la Reumatologia, Buenos Aires, Argentina

${ }^{2}$ Instituto Universitario

Escuela de Medicina Hospital Italiano de Buenos Aires, Buenos Aires, Argentina
}

Correspondence to Professor Enrique R Soriano; enrique.soriano@ hospitalitaliano.org.ar

\title{
Incidence and prevalence of lupus in Buenos Aires, Argentina: a 11-year health management organisation-based study
}

\author{
M Scolnik, ${ }^{1,2} \mathrm{~J}$ Marin, ${ }^{1,2} \mathrm{~S}$ M Valeiras, ${ }^{2}$ M F Marchese, ${ }^{2}$ A S Talani, ${ }^{2}$ \\ $\mathrm{N}$ L Avellaneda, ${ }^{2}$ A Etchepare, ${ }^{2} \mathrm{P}$ Etchepare, ${ }^{2} \mathrm{M} S \mathrm{Plou},{ }^{2} \mathrm{E}$ R Soriano ${ }^{1,2}$
}

\section{ABSTRACT}

Objectives: Studies regarding the epidemiology of systemic lupus erythematosus (SLE) are lacking in Argentina. Our purpose was to estimate the incidence and prevalence of SLE in a university hospital-based health management organisation in Buenos Aires (HIMCP). Methods: For incidence calculation, the population at risk included all adult members of the HIMCP, with continuous affiliation for at least 1 year from January 1998 to January 2009. Each person was followed until he/she voluntarily left the HIMICP, death or finalisation of the study. Multiple methods for case finding were used to ensure complete ascertainment: (a) patients with problem SLE, undifferentiated autoimmune disease or mixed connective tissue disease in the Computer-based Patient Record System, (b) patients with positive antinuclear antibody test, anti-Sm antibodies and/or anti-dsDNA antibodies in the laboratory database and (c) patients who consumed hydroxichloroquine, chloroquine, azathioprine, cyclophosphamide, mycophenolate, cyclosporine or rituximab, from the administrative HIMCP drugs database. Medical records of all patients found were reviewed, and only patients fulfilling ACR criteria for SLE were included. Global and gender incidence rate (IR) was calculated. Prevalence was estimated on 1 January 2009, and the denominator population was the number of active members $>18$ years at that date $(\mathrm{n}=127959)$.

Results: In the study period, 68 patients developed SLE. The observed IR (per 100000 person-years, (Cl 95\%)) was 6.3 (4.9 to 7.7) for total population; 8.9 (Cl 6.6 to 11.2) for women and 2.6 (1.2 to 3.9$)$ for men. On 1 January 2009, 75 prevalent cases were identified. Prevalence rates (cases per 100000 habitants, (CI 95\%)) were 58.6 (46.1 to 73.5 ) for total population; 83.2 (63.9 to 106.4) for women and 23 (Cl 11.9 to 40.1) for men.

Conclusions: SLE incidence and prevalence rates in Argentina are in agreement with those of other studies from different parts of the world.

\section{INTRODUCTION}

The prevalence and incidence of systemic lupus erythematosus (SLE) reported in published studies have remarkable disparities across countries. ${ }^{1}$

\section{KEY MESSAGES}

- Incidence and prevalence rates of lupus in Buenos Aires, Argentina were similar to those reported in other studies in Latin America and USA.

- Females incidence rate peak was on the 20 s and prevalence rate peak on the 40 s and $50 \mathrm{~s}$.

- Male incidence and prevalence rates were lower and similar among all age groups.

Study methodologies differ and interpretation of results has limitations. ${ }^{2}$ These limitations include lack of standardised criteria for case detection, passive methods of case ascertainment that miss mild cases (ie, review of inpatient medical records), studies conducted in small geographic areas that make generalisation difficult, studies using self-report or self-report physician diagnosis that report a much higher prevalence (including patients who may not meet strict criteria), and so on. ${ }^{2}$

The majority of SLE epidemiology studies have been performed in the USA and Europe and most of them have been performed using Caucasian cohorts. ${ }^{1}$ Several studies have shown that SLE more frequently affects nonCaucasian individuals; prevalence of SLE in the USA is higher in African-Americans, Hispanics and Asians than in Caucasians. ${ }^{1}$ Additional studies are needed to clarify potential aetiologies, such as genetic factors with regional variation in gene pools and environmental factors including infections, latitude, sun exposure, toxins and diet, which could explain differences in the epidemiology of SLE around the world.

In this sense, scarce data are available on lupus epidemiology in Latin America and in particular in Argentina. Our objective was to estimate the incidence and prevalence of SLE in a university hospital-based health management organisation in Buenos Aires (HIMCP), Argentina. 


\section{METHODS}

\section{Setting}

The population studied was the membership of the Hospital Italiano Medical Care Program, a prepaid health maintenance organisation in Buenos Aires, Argentina. Hospital Italiano Medical Care program provides comprehensive medical and health services through two main hospitals and 24 peripheral outpatient centres to around 140000 members primarily located in the urban areas around the city of Buenos Aires, Argentina. The city covers an area of $202 \mathrm{~km}^{2}$ and has a subtropical climate. It is located on the western bank of the 'Rio de la Plata' and has a population of 2890151 inhabitants (2010 census). ${ }^{3}$ In all, 92\% of the population is white and of European descent, and the remaining is a mixture of natives and other ethnicities ${ }^{3}$ (see online supplementary tables S1-S2).

Argentina has a segmented health system consisting of three large sectors: public, private and social security (the last two covering a population of nearly 18.3 million people, distributed among close to 300 entities of varying scope and size). Beneficiaries of the private system can freely choose their health maintenance organisation.

In this context, the Hospital Italiano Medical Care Program is a private health system insurance selected by many city inhabitants because of a perceived excellence of the services provided as well as the affordability of the insurance. Approximately $5 \%-7 \%$ of the population in these geographic areas is affiliated to the Hospital Italiano Medical Care Program. Despite the previously mentioned limitations, the characteristics of these population are fairly representative of the metropolitan population of the city of Buenos Aires, covering a number of demographic and socioeconomic categories ${ }^{3}{ }^{4}$ (see online supplementary tables S1-S3).

\section{Population}

For incidence calculation, the population at risk was that of all adult members (aged >18 years) of the HIMCP, with continuous affiliation for at least 1 year from January 1998 to January 2009. Each person was followed up until he/she was diagnosed with SLE, voluntarily left the Hospital Italiano Medical Care Program, death, or finalisation of the study (final dates) contributing time at risk since January 1998 or enrolment date (whichever occurred later) to the final date.

\section{Case ascertainment}

Multiple methods for case finding were used to ensure complete ascertainment: (a) patients with problem SLE, undifferentiated autoimmune disease or mixed connective tissue disease in the Hospital Italiano Medical Care Program problem oriented Computer-based Patient Record System, (b) patients with positive Antinuclear antibody test titer $>1 / 160$ and/or positive anti-Sm antibodies and/ or anti-dsDNA antibodies in the Hospital laboratory database and (c) patients who consumed hydroxichloroquine, chloroquine, azathioprine, cyclophosphamide, mycophenolate mofetil, cyclosporine and/or rituximab, from the administrative Hospital Italiano Medical Care Program drugs database. Medical records of all patients found were reviewed, and only patients fulfilling American College of Rheumatology (ACR) criteria for $\mathrm{SLE}^{5}$ were included.

\section{Statistical analysis}

Global and gender incidence rate was calculated with 95\% CIs. For incidence calculation, the date of diagnosis was considered as that when the diagnosis first appeared in the clinical records and cases had to have been enrolled with the Hospital Italiano Medical Care Program for at least 1 year before this date. Prevalence was estimated in January 2009, and the denominator population was the number of adult Hospital Italiano Medical Care Program active members on that date $(n=127$ 959). Age- and sex-specific incidence and prevalence rate with their $95 \%$ CIs were also calculated.

\section{RESULTS}

Incidence

In the study period, 186086 persons contributed a total of 1082817.6 person-years. A total of 68 patients developed SLE between 1998 and 1 January 2009. The overall incidence rate was 6.3 (CI 95\%: 4.9 to 7.7) cases per 100000 person-years. All patients were from Caucasian ethnicity.

Overall, 57 of the new onset SLE were women (83.8\%), with an incidence rate of 8.9 (CI 95\%: 6.6 to 11.2) cases per 100000 person-years. Incidence rate for men was 2.6 (CI 1.2 to 3.9) cases per 100000 personyears (figure 1). Age-specific incidence rates (figure 2A) in female patients peaked in the 20s, while the rates for male patients appeared more constant across age groups. In older age groups, incidence rates among women and men were much closer than in younger patients (figure 2A).

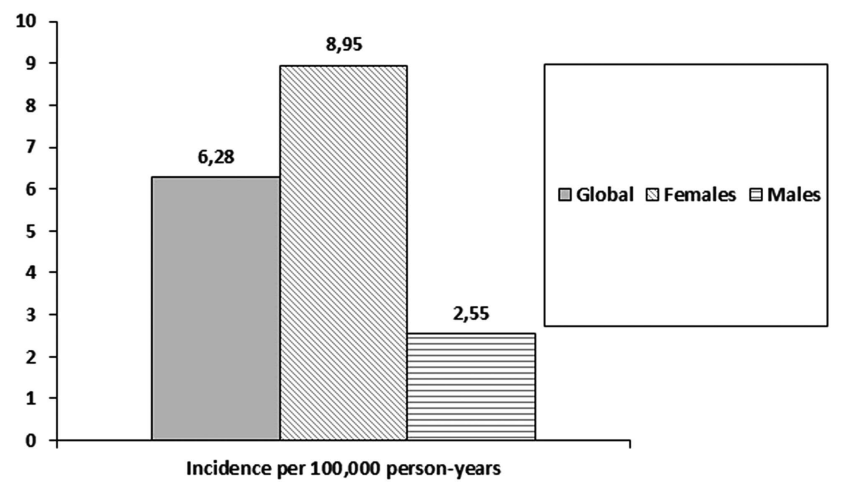

Figure 1 Incidence of systemic lupus erythematosus by gender. 

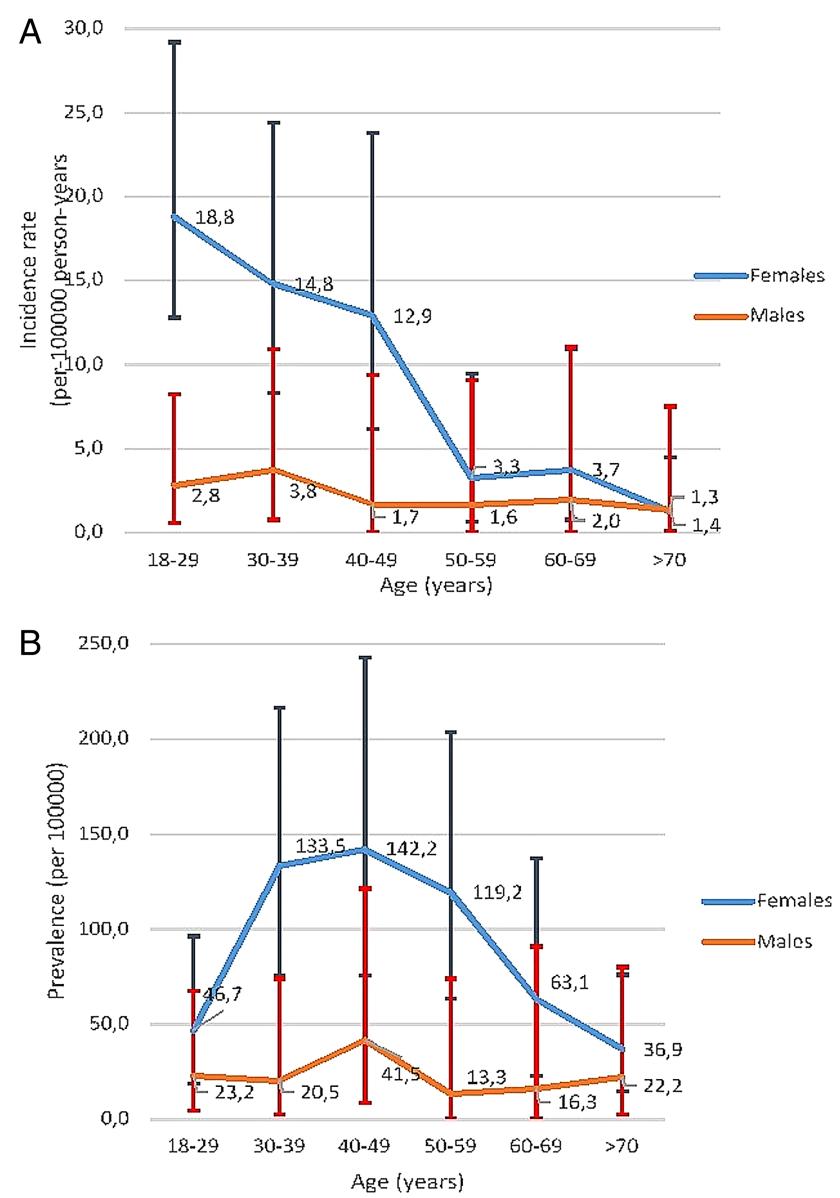

Figure 2 Age-specific average annual incidence $(A)$ and prevalence (B) rates (per 100000 persons) of systemic lupus erythematosus, categorised by sex. Values are the point estimate and bars show the $95 \%$ confidence intervals.

\section{Prevalence}

On 1 January 2009, 75 prevalent cases were identified. Denominator population was the number of active members over 18 years old at that date $(n=127959)$. Prevalence rate was 58.6 (CI 95\% 46.1 to 73.5) cases per 100000 inhabitants (women 83.2 (CI 95\%: 63.9 to 106.4) and men 23 (CI 95\% 11.9 to 40.1 ) per 100000 members) (figure 3). Age-specific prevalent rates are shown in table 2B. Among women, SLE was more prevalent in the 40s and 50s. The peak prevalence among men was in the $40 \mathrm{~s}$.

Comparison with data published from other parts of the world is shown in table 1 .

\section{DISCUSSION}

The variability in incidence and prevalence estimates of SLE around the world can be attributed to true disparities across the countries or may result from the methodological differences among the studies. Data in table 1 provide a summary of studies performed around the world showing some differences among different countries.

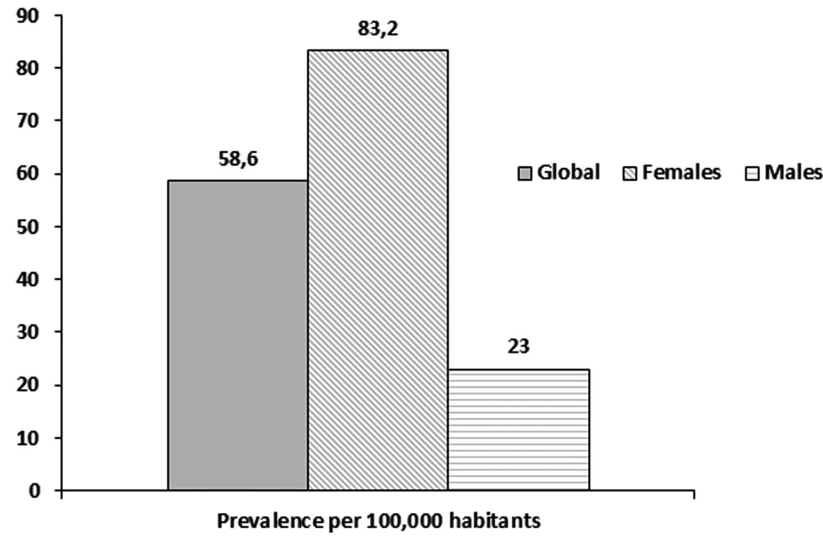

Figure 3 Incidence of systemic lupus erythematosus by gender.

The influences of ethnic, social and demographic variables on the clinical characteristics of SLE patients have already been shown by many studies. ${ }^{42-53}$ In series from both the USA and Europe, more severe disease was noticed in non-Caucasian populations (Hispanics, African descendants and Asians) than in Caucasians. ${ }^{43} 474852$ 54-58

Latin America is a large subcontinent rich in the variety of racial admixtures between and within countries. In addition, socioeconomic, educational and demographic variations are prominent. In consequence, the apparent homogeneity of Latin Americans is a myth, and within the subcontinent lies great diversity. ${ }^{59}$

Little information on SLE is available from Latin America. ${ }^{59-75}$

Several studies from the USA have included Latin American patients, usually referring to them as 'Hispanics', 55 56 76-80 a term that is mainly derived from their language rather than their ethnic background. Despite this, the so-called Hispanics in the USA have been shown to have more severe disease and poorer outcomes than white Americans, ${ }^{76}{ }^{80}$ probably because they usually share low socioeconomic status (SES) and Amerindian background, both associated with more sever lupus.

By January 2001, the Grupo Latinoamericano de Estudio del Lupus (GLADEL) cohort included 1214 patients from 34 centres from nine Latin American countries. There were 537 mestizos (44\%), 507 white patients (42\%) and 152 African-Latin Americans (ALA) $(13 \%)$. There were small numbers of pure Amerindian and oriental individuals. White patients predominated in Argentina and Cuba and in a lesser degree in Brazil. Mestizos predominated in Guatemala, Mexico and Peru. ALA patients were more prevalent in Venezuela, Brazil and Colombia. ${ }^{59}$

In the GLADEL cohort, both ALA and mestizos had more severe disease than white patients, as evidenced by a higher frequency of renal disease, pericarditis, polyadenopathy and discoid lesions in ALA. Mestizos and ALA had lower SES, fewer years of formal education and less 
Table 1 Data on SLE incidence and prevalence around the world

\begin{tabular}{|c|c|c|c|c|}
\hline Area & Authors & Study period & $\begin{array}{l}\text { Incidence (cases per } \\
100000 \text { persons-years) }\end{array}$ & $\begin{array}{l}\text { Prevalence } \\
\text { (cases per } \\
100000 \\
\text { habitants) }\end{array}$ \\
\hline \multicolumn{5}{|l|}{ Europe } \\
\hline Iceland & $\begin{array}{l}\text { Gudmundsson and } \\
\text { Steinsson }^{6}\end{array}$ & $1975-1984$ & 3.3 & 35.9 \\
\hline Denmark & Voss et $a^{\rho}$ & 1980-1994 & 3.6 & 21.7 \\
\hline Sweden & Nived et $a l^{10}$ & 1981-1982 & 4.8 & 39 \\
\hline Greece & Alamanos et al ${ }^{11}$ & $1982-2001$ & 1.9 & 38 \\
\hline Sweden & Ståhl-Hallengren et al ${ }^{12}$ & 1986-1991 & 4.8 & $42-68$ \\
\hline Spain & Alonso et $a l^{13}$ & 1987-2006 & 3.6 & 17.5 \\
\hline UK & Hopkinson et al ${ }^{14}$ & $1989-1990$ & 4 & 24.6 \\
\hline Denmark & Laustrup et $a l^{18}$ & 1995-2003 & 1 & 28.3 \\
\hline Italy & Govoni et al ${ }^{19}$ & 1996-2002 & 2.6 & 57.9 \\
\hline \multicolumn{5}{|l|}{ USA } \\
\hline USA & Fessel $^{20}$ & 1965-1973 & 7.6 & 50.8 \\
\hline USA & Hochberg $^{21}$ & 1970-1977 & 4.6 & - \\
\hline USA & Michet et $a{ }^{2}$ & 1970-1979 & 2.2 & 40 \\
\hline USA & Uramoto et $a^{23}$ & 1980-1992 & 5.6 & 130 \\
\hline USA & McCarty et $a^{R^{4}}$ & 1985-1990 & 2.4 & - \\
\hline USA & Naleway et $a^{25}$ & 1991-2001 & 5.1 & 78.5 \\
\hline USA & Balluz et $a^{26}$ & 1997 & - & 103 \\
\hline \multicolumn{5}{|l|}{ Latin America } \\
\hline Curacao island & Nossent $^{27}$ & 1980-1989 & 4.6 & 47.6 \\
\hline \multicolumn{5}{|l|}{ Asia } \\
\hline Japan & Iseki et $\left.a\right|^{\beta 4}$ & 1972-1991 & $0.9-2.9$ & $3.7-37.7$ \\
\hline Japan & Kameda ${ }^{35}$ & 1975-1977 & 1 & 10.8 \\
\hline Asian-Pacific region & Jakes et $a \beta^{\beta 6}$ & 1973-2006 & $0.9-3.1$ & $4.3-45.3$ \\
\hline Saudi Arabia & Al-Arfaj et $a{ }^{\beta 7}$ & 1992 & - & 19.3 \\
\hline Hong Kong & Mok et $a \beta^{\beta 8}$ & 2000-2006 & 3.1 & - \\
\hline Russian Federation & Nasonov et a ${ }^{\beta 9}$ & 2010 & 1.4 & 9 \\
\hline Kazakhstan & Nasonov et $a^{\beta 9}$ & 2010 & 1.6 & 20.6 \\
\hline Ukraine & Nasonov et $a^{\beta 9}$ & 2010 & 0.3 & 14.9 \\
\hline \multicolumn{5}{|l|}{ Oceania } \\
\hline Australia & Anstey et $a f^{40}$ & 1984-1991 & 11 & 52.6 \\
\hline Australia & Bossingham $^{41}$ & 1998 & - & 45.3 \\
\hline
\end{tabular}

accessibility to medical care than white patients, and these socioeconomic factors may have a bearing on the more severe disease found in non-whites. ${ }^{59}$

No data have been published before on incidence and prevalence of SLE in Argentina. Our study has some limitations. It was performed in a health maintenance organisation and therefore contains some selection bias.
However, as shown in online supplementary tables S1 and S2, comparison of this health maintenance organisation population with that of the city of Buenos Aires shows that it is fairly representative of that population, although there are some differences, mainly in the SES. These differences might affect the prevalence as patients with poorest SES have less survival. However, we think 
that with caution, results obtained in this study could be extrapolated to the whole city of Buenos Aires. Buenos Aires population may not be representative of the complete Argentinian population since it has mainly a European origin, showing a lesser proportion of mestizos than the rest of the country. For example, Argentinian SLE patients included in GLADEL (also a non-randomised Argentinian sample) were $17.1 \%$ mestizos, while in our study only $2.3 \%$ were mestizos. Due to the low number of persons from other ethnicities, we were unable to compare the epidemiology of the disease according to ethnic origin; in fact, all patients were classified as white in our study. As the study was undertaken in a healthcare organisation where 'ill' patients are not incorporated, we may have a bias when considering prevalent cases because patients with existing disease would not have been allowed to enter the health maintenance organisation. This fact did not appear to have a great effect as our prevalence is similar to other studies, and this limitation would not affect incidence rates.

Despite these limitations, this study provides the first estimation of the incidence and prevalence of SLE in Argentina using the same methodology we used in previous studies with other rheumatic diseases. ${ }^{81-83}$

More efforts are needed to achieve a better characterisation of the Argentinian lupus population in order to understand the burden of SLE in the country. A more profound knowledge of the local lupus epidemiology may allow establishing country-specific healthcare policies.

\section{CONCLUSIONS}

Incidence and prevalence of SLE in this study population from Argentina were within the range of estimates previously reported in other countries.

Contributors All authors contributed to the conception and design of the study, acquisition and/or interpretation of data, drafting the article or revising it critically for important intellectual content and approved the final version of the manuscript.

Funding This study was funded by Rheumatology Section, Medical Services, Hospital Italiano de Buenos Aires.

Competing interests None.

Ethical approval We received confirmation from our Ethical Committee that ethics approval was not required for this retrospective study.

Provenance and peer review Not commissioned; externally peer reviewed.

Data sharing statement No additional data are available.

Open Access This is an Open Access article distributed in accordance with the Creative Commons Attribution Non Commercial (CC BY-NC 3.0) license, which permits others to distribute, remix, adapt, build upon this work noncommercially, and license their derivative works on different terms, provided the original work is properly cited and the use is non-commercial. See: http:// creativecommons.org/licenses/by-nc/3.0/

\section{REFERENCES}

1. Danchenko N, Satia JA, Anthony MS. Epidemiology of systemic lupus erythematosus: a comparison of worldwide disease burden. Lupus 2006;15:308-18.
2. Pons-Estel GJ, Alarcón GS, Scofield L, et al. Understanding the epidemiology and progression of systemic lupus erythematosus. Semin Arthritis Rheum 2010;39:257-68.

3. INDEC. Direccion general de estadisticas y censos. Argentina: Censo Nacional de poblacion, hogares y vivienda, 2010. http://www. indec.gov.ar/ (last acceded 28 Jan 2014).

4. Dirección General de Estadística y Censos. Ministerio de Hacienda. Gobierno de la ciudad de Buenos Aires. Anuario Estadistico. 2009 http://www.estadistica.buenosaires.gob.ar/areas/hacienda/sis estadistico/buscador.php?menu_id=18675 (last acceded 28 Jan 2014).

5. Hochberg MC. Updating the American College of Rheumatology revised criteria for the classification of systemic lupus erythematosus. Arthritis Rheum 1997;40:1725.

6. Gudmundsson S, Steinsson K. Systemic lupus erythematosus in Iceland 1975 through 1984. A nationwide epidemiological study in an unselected population. J Rheumatol 1990;17:1162-7.

7. Helve T. Prevalence and mortality rates of systemic lupus erythematosus and causes of death in SLE patients in Finland. Scand J Rheumatol 1985;14:43-6.

8. Nossent HC. Systemic lupus erythematosus in the Arctic region of Norway. J Rheumatol 2001;28:539-46.

9. Voss A, Green A, Junker P. Systemic lupus erythematosus in Denmark: clinical and epidemiological characterization of a county-based cohort. Scand J Rheumatol 1998;27:98-105.

10. Nived O, Sturfelt G, Wollheim F. Systemic lupus erythematosus in an adult population in southern Sweden: incidence, prevalence and validity of ARA revised classification criteria. $\mathrm{Br} J$ Rheumatol 1985;24:147-54.

11. Alamanos $\mathrm{Y}$, Voulgari $\mathrm{PV}$, Siozos $\mathrm{C}$, et al. Epidemiology of systemic lupus erythematosus in northwest Greece 1982-2001. J Rheumatol 2003;30:731-5.

12. Ståhl-Hallengren $\mathrm{C}$, Jönsen $\mathrm{A}$, Nived $\mathrm{O}$, et al. Incidence studies of systemic lupus erythematosus in Southern Sweden: increasing age, decreasing frequency of renal manifestations and good prognosis. $J$ Rheumatol 2000;27:685-91.

13. Alonso MD, Llorca J, Martinez-Vazquez F, et al. Systemic lupus erythematosus in northwestern Spain: a 20-year epidemiologic study. Medicine (Baltimore) 2011;90:350-8.

14. Hopkinson ND, Doherty M, Powell RJ. The prevalence and incidence of systemic lupus erythematosus in Nottingham, UK 1989-1990. Br J Rheumatol 1993;32:110-15.

15. Johnson AE, Gordon C, Palmer RG, et al. The prevalence and incidence of systemic lupus erythematosus in Birmingham, England. Relationship to ethnicity and country of birth. Arthritis Rheum 1995;38:551-8.

16. Gourley IS, Patterson CC, Bell AL. The prevalence of systemic lupus erythematosus in Northern Ireland. Lupus 1997;6:399-403.

17. López $\mathrm{P}$, Mozo L, Gutiérrez C, et al. Epidemiology of systemic lupus erythematosus in a northern Spanish population: gender and age influence on immunological features. Lupus 2003;12:860-5.

18. Laustrup $H$, Voss A, Green A, et al. Occurrence of systemic lupus erythematosus in a Danish community: an 8-year prospective study. Scand J Rheumatol 2009;38:128-32.

19. Govoni M, Castellino G, Bosi S, et al. Incidence and prevalence of systemic lupus erythematosus in a district of north Italy. Lupus 2006;15:110-13.

20. Fessel WJ. Systemic lupus erythematosus in the community. Incidence, prevalence, outcome, and first symptoms; the high prevalence in black women. Arch Intern Med 1974; 134:1027-35.

21. Hochberg MC. The incidence of systemic lupus erythematosus in Baltimore, Maryland, 1970-1977. Arthritis Rheum 1985;28:80-6.

22. Michet CJ, McKenna CH, Elveback LR, et al. Epidemiology of systemic lupus erythematosus and other connective tissue diseases in Rochester, Minnesota, 1950 through 1979. Mayo Clin Proc 1985;60:105-13.

23. Uramoto KM, Michet CJ, Thumboo J, et al. Trends in the incidence and mortality of systemic lupus erythematosus, 1950-1992. Arthritis Rheum 1999;42:46-50.

24. McCarty DJ, Manzi S, Medsger TA, et al. Incidence of systemic lupus erythematosus. Race and gender differences. Arthritis Rheum 1995;38:1260-70.

25. Naleway AL, Davis ME, Greenlee RT, et al. Epidemiology of systemic lupus erythematosus in rural Wisconsin. Lupus 2005;14:862-6.

26. Balluz L, Philen R, Ortega L, et al. Investigation of systemic lupus erythematosus in Nogales, Arizona. Am J Epidemiol 2001;154:1029-36.

27. Nossent JC. Systemic lupus erythematosus on the Caribbean island of Curaçao: an epidemiological investigation. Ann Rheum Dis 1992;51:1197-201. 
28. Deligny C, Thomas L, Dubreuil F, et al. [Systemic lupus erythematosus in Martinique: an epidemiologic study]. Rev Med Interne 2002;23:21-9.

29. Senna ER, De Barros ALP, Silva EO, et al. Prevalence of rheumatic diseases in Brazil: a study using the COPCORD approach. $J$ Rheumatol 2004:31:594-7.

30. Vilar MJP, Sato El. Estimating the incidence of systemic lupus erythematosus in a tropical region (Natal, Brazil). Lupus 2002;11:528-32.

31. Gamboa R, Medina M, Acevedo E, et al. Prevalencia de enfermedades reumatológicas y discapacidad en una comunidad urbano-marginal: resultados del primer estudio COPCORD en el Perú. Rev Per Reuma 2009;15:40-6.

32. Peláez-Ballestas I, Sanin LH, Moreno-Montoya J, et al. Epidemiology of the rheumatic diseases in Mexico. A study of 5 regions based on the COPCORD methodology. J Rheumatol Suppl 2011;86:3-8.

33. Reyes-Llerena GA, Guibert-Toledano M, Penedo-Coello A, et al. Community-based study to estimate prevalence and burden of illness of rheumatic diseases in Cuba: a COPCORD study. J Clin Rheumatol 2009;15:51-5.

34. Iseki K, Miyasato F, Oura T, et al. An epidemiologic analysis of end-stage lupus nephritis. Am J Kidney Dis 1994;23:547-54

35. Kameda S. Epidemiologic study of systemic lupus erythematosus in Fukuoka population. Fukuoka Igaku Zasshi 1988;79:571-8.

36. Jakes RW, Bae S-C, Louthrenoo W, et al. Systematic review of the epidemiology of systemic lupus erythematosus in the Asia-Pacific region: prevalence, incidence, clinical features, and mortality. Arthritis Care Res (Hoboken) 2012;64:159-68.

37. Al-Arfaj AS, Al-Balla SR, Al-Dalaan AN, et al. Prevalence of systemic lupus erythematosus in central Saudi Arabia. Saudi Med J 2002;23:87-9.

38. Mok CC, To CH, Ho LY, et al. Incidence and mortality of systemic lupus erythematosus in a southern Chinese population, 2000-2006. $J$ Rheumatol 2008;35:1978-82.

39. Nasonov E, Soloviev S, Davidson J, et al. The prevalence and incidence of Systemic Lupus Erythematosus (SLE) in selected cities from three Commonwealth of Independent States countries (the Russian Federation, Ukraine and Kazakhstan). Lupus 2014;23:213-19.

40. Anstey NM, Bastian I, Dunckley H, et al. Systemic lupus erythematosus in Australian aborigines: high prevalence, morbidity and mortality. Aust N Z J Med 1993;23:646-51.

41. Bossingham D. Systemic lupus erythematosus in the far north of Queensland. Lupus 2003;12:327-31.

42. Devins GM, Edworthy SM. Illness intrusiveness explains race-related quality-of-life differences among women with systemic lupus erythematosus. Lupus 2000;9:534-41.

43. Ginzler EM, Diamond HS, Weiner M, et al. A multicenter study of outcome in systemic lupus erythematosus. I. Entry variables as predictors of prognosis. Arthritis Rheum 1982;25:601-11.

44. Halberg P, Alsbjørn B, Balslev JT, et al. Systemic lupus erythematosus. Follow-up study of 148 patients. II: Predictive factors of importance for course and outcome. Clin Rheumatol 1987;6:22-6.

45. Karlson EW, Daltroy LH, Lew RA, et al. The relationship of socioeconomic status, race, and modifiable risk factors to outcomes in patients with systemic lupus erythematosus. Arthritis Rheum 1997; 40:47-56.

46. Karlson EW, Daltroy LH, Lew RA, et al. The independence and stability of socioeconomic predictors of morbidity in systemic lupus erythematosus. Arthritis Rheum 1995;38:267-73.

47. Petri M, Perez-Gutthann S, Longenecker JC, et al. Morbidity of systemic lupus erythematosus: role of race and socioeconomic status. Am J Med 1991;91:345-53.

48. Reveille JD, Bartolucci A, Alarcón GS. Prognosis in systemic lupus erythematosus. Negative impact of increasing age at onset, black race, and thrombocytopenia, as well as causes of death. Arthritis Rheum 1990;33:37-48.

49. Seleznick MJ, Fries JF. Variables associated with decreased survival in systemic lupus erythematosus. Semin Arthritis Rheum 1991;21:73-80.

50. Studenski S, Allen NB, Caldwell DS, et al. Survival in systemic lupus erythematosus. A multivariate analysis of demographic factors. Arthritis Rheum 1987;30:1326-32.

51. Trager J, Ward MM. Mortality and causes of death in systemic lupus erythematosus. Curr Opin Rheumatol 2001;13:345-51.

52. Walsh SJ, Algert C, Gregorio DI, et al. Divergent racial trends in mortality from systemic lupus erythematosus. $J$ Rheumatol 1995;22:1663-8.

53. Ward MM, Pyun E, Studenski S. Long-term survival in systemic lupus erythematosus. Patient characteristics associated with poorer outcomes. Arthritis Rheum 1995;38:274-83.
54. González LA, Toloza SMA, McGwin G, et al. Ethnicity in systemic lupus erythematosus (SLE): its influence on susceptibility and outcomes. Lupus 2013;22:1214-24.

55. Alarcón GS, Friedman AW, Straaton KV, et al. Systemic lupus erythematosus in three ethnic groups: III. A comparison of characteristics early in the natural history of the LUMINA cohort. LUpus in Mlnority populations: NAture vs. Nurture. Lupus 1999;8:197-209.

56. Alarcón GS, Rodríguez JL, Benavides G, et al. Systemic lupus erythematosus in three ethnic groups. V. Acculturation, health-related attitudes and behaviors, and disease activity in Hispanic patients from the LUMINA cohort. LUMINA Study Group. Lupus in Minority Populations, Nature versus Nurture. Arthritis Care Res 1999:12:267-76.

57. Kaslow RA. High rate of death caused by systemic lupus erythematosus among U. S. residents of Asian descent. Arthritis Rheum 1982;25:414-18.

58. Thumboo J, Uramoto K, O'Fallon WM, et al. A comparative study of the clinical manifestations of systemic lupus erythematosus in Caucasians in Rochester, Minnesota, and Chinese in Singapore, from 1980 to 1992. Arthritis Rheum 2001;45:494-500

59. Pons-Estel BA, Catoggio LJ, Cardiel MH, et al. The GLADEL multinational Latin American prospective inception cohort of 1,214 patients with systemic lupus erythematosus: ethnic and disease heterogeneity among "Hispanics". Medicine (Baltimore) 2004;83:1-17

60. Bellomio V, Spindler A, Lucero E, et al. Systemic lupus erythematosus: mortality and survival in Argentina. A multicenter study. Lupus 2000;9:377-81.

61. Drenkard C, Villa AR, Garcia-Padilla C, et al. Remission of systematic lupus erythematosus. Medicine (Baltimore) 1996;75:88-98.

62. Fernandez RN, Rego JNA. LES: experiencia de 5 anos. Rev Bras Rheumatol Suppl 1992;32:41.

63. Harris EN, Williams E, Shah DJ, et al. Mortality of Jamaican patients with systemic lupus erythematosus. Br J Rheumatol 1989; 28:113-17.

64. Hernández-Cruz B, Tapia N, Villa-Romero AR, et al. Risk factors associated with mortality in systemic lupus erythematosus. A case-control study in a tertiary care center in Mexico City. Clin Exp Rheumatol 2001;19:395-401.

65. Johnson AE, Cavalcanti FS, Gordon C, et al. Crosssectional analysis of the differences between patients with systemic lupus erythematosus in England, Brazil and Sweden. Lupus 1994:3:501-6

66. Massardo L, Jacobelli S. Occasional series: lupus around the world. The Chilean experience of systemic lupus erythematosus. Lupus 1996;5:175-7.

67. Massardo L, Martínez ME, Jacobelli S, et al. Survival of Chilean patients with systemic lupus erythematosus. Semin Arthritis Rheum 1994;24:1-11.

68. Molina JF, Drenkard C, Molina J, et al. Systemic lupus erythematosus in males. A study of 107 Latin American patients. Medicine (Baltimore) 1996;75:124-30.

69. Nossent JC. Course and prognostic value of systemic lupus erythematosus disease activity index in black caribbean patients. Semin Arthritis Rheum 1993;23:16-21.

70. Rojas-Serrano J, Cardiel MH. Lupus patients in an emergency unit. Causes of consultation, hospitalization and outcome. A cohort study. Lupus 2000;9:601-6.

71. Vilá LM, Mayor AM, Valentín AH, et al. Clinical and immunological manifestations in 134 Puerto Rican patients with systemic lupus erythematosus. Lupus 1999;8:279-86.

72. Pons-Estel GJ, Alarcón GS, Hachuel L, et al. Anti-malarials exert a protective effect while Mestizo patients are at increased risk of developing SLE renal disease: data from a Latin-American cohort. Rheumatology (Oxford) 2012;51:1293-8.

73. Bellomio V, Spindler A, Lucero E, et al. Metabolic syndrome in Argentinean patients with systemic lupus erythematosus. Lupus 2009;18:1019-25.

74. Seldin MF, Qi L, Scherbarth HR, et al. Amerindian ancestry in Argentina is associated with increased risk for systemic lupus erythematosus. Genes Immun 2008;9:389-93.

75. Garcia MA, Marcos JC, Marcos Al, et al. Male systemic lupus erythematosus in a Latin-American inception cohort of 1214 patients. Lupus 2005;14:938-46.

76. Alarcón GS, McGwin G, Bartolucci AA, et al. Systemic lupus erythematosus in three ethnic groups. IX. Differences in damage accrual. Arthritis Rheum 2001;44:2797-806. 
77. Alarcón GS, McGwin G, Bastian HM, et al. Systemic lupus erythematosus in three ethnic groups. VII [correction of VIII]. Predictors of early mortality in the LUMINA cohort. LUMINA Study Group. Arthritis Rheum 2001:45:191-202.

78. Alarcón GS, McGwin G, Petri M, et al. Baseline characteristics of a multiethnic lupus cohort: PROFILE. Lupus 2002;11:95-101.

79. Quintero-Del-Rió Al, Bacino D, Kelly J, et al. Familial systemic lupus erythematosus: a comparison of clinical manifestations and antibody presentation in three ethnic groups. Cell Mol Biol (Noisy-le-grand) 2001;47:1223-7.

80. Alarcón GS, Roseman J, Bartolucci AA, et al. Systemic lupus erythematosus in three ethnic groups: II. Features predictive of disease activity early in its course. LUMINA Study Group. Lupus in minority populations, nature versus nurture. Arthritis Rheum 1998;41:1173-80

81. Soriano ER, Rosa J, Velozo E, et al. Incidence and prevalence of psoriatic arthritis in Buenos Aires, Argentina: a 6-year health management organization-based study. Rheumatology (Oxford) 2011;50:729-34.

82. Rosa J, Garrot LF, Navarta DA, et al. Incidence and prevalence of polymyositis and dermatomyositis in a health management organization in Buenos Aires. J Clin Rheumatol 2013;19:303-7.

83. Rosa JE, Soriano ER, Narvaez-Ponce L, et al. Incidence and prevalence of systemic sclerosis in a healthcare plan in Buenos Aires. J Clin Rheumatol 2011;17:59-63. 